one aspect of metabolic pathway in developing or differentiating cells.

\title{
Conclusion
}

1) Histochemical observations of enzymes were made on fourth to seventh month human skin.

2) Acid phosphatase and non-specific esterase showed stronger reaction in embryonal skin than in adult, and other 10 enzymes showed weaker reaction in embryo.

3) All enzyme activities which were observed showed gradual intensifing of activities according to the course of the development, and the strongest reaction was obtained in sixth or seventh month of fetal life.

4) Some enzyme activities showed peculiar occurence in embryonic stage alone, i.e., NAD-linked isocitric dehydrogenase, NAD-linked malic dehydrogenase and NAD-linked lactic dehydrogenase were found in periderm, alkaline phosphatase was in basal layer of epidermis and acid phosphatase was found in hair papilla and connective tissue.

\section{Histochemische und Elektronenmikroskopische Untersuchungen an Zirbeldrüsen von}

Säugetieren

\author{
T. Mashimo
}

Anatomisches Institut (Prof. Y. Sano), Medizinische Akademie Kyoto, Kyoto

Auf die vielerörterte Frage nach der funktionellen Bedeutung der Epiphyse läßt sich bisher keine auch nur annähernd befriedigende Antwort erteilen. Zwar wird das rätselhafte Organ in die Reihe der inkretorischen Drüsen eingegliedert, doch rechtfertigen weder histologische noch physiologische Befunde diese Eingruppierung vollkommend. In der vorliegenden Studie wird die Epiphyse von einigen Säugetieren histochemisch sowie elektronenmikroskopisch im Hinblick auf ihre sekretorische Funktion untersucht.

\section{Material und Methodik}

Die Epiphyse junger Hunde, Katzen und Ratten (1-8 Wochen alt) beiderlei Geschlechtes gelangte zur histochemischen Untersuchung. Nach Dekapitation wurde das frische nichtfixierte Material im Kryostat geschnitten, oder je mit 10\% Folmol, 6.5\% Glutalaldehyd, Bouinschem, Carnoyschem und Hamazakische D Gemisch fixiert. Anfertigung von Paraffinschnitten bzw, von Gefrierschnitten. 
Histochemische Reaktionen : Sudan III, Sudanschwarz B, Ketoenol-Reaktion nach Hamazaki, PJS, chromaffine Reaktion nach Borberg, argentaffine Reaktion nach Masson, Reaktionen für alkalische und saure Phosphatase nach Gomori, Monoaminoxydase nach Glenner, Aminopeptidase nach Nachlas et al., Cholinesterase nach Sávay et al., (Tabelle)

Tabelle Resultate für die histochemischen Reaktionen in der Epiphyse.

\begin{tabular}{l|l|ccc}
\multicolumn{1}{c|}{ Substanz } & \multicolumn{1}{|c|}{ Reaktion } & Hund & Katze & Ratte \\
\hline Fett & Sudan III & + & + & Ht \\
Glykogen & Sudanschwarz B & + & + & Ht \\
Ketoenolsubstanz & PJS & - & - & \\
Catecholamin & HAMAZAKI & + & + & \\
& MASSON & - & - & \\
Alkalische Phosphatase & BORBERG & - & - & \\
Saure Phosphatase & GOMORI & + & + & \\
Monoaminoxydase & GOMORI & + & + & \\
Aminopeptidase & GLENNER & - & - & fH \\
Cholinesterase & NACHLAS et al. & & - & \\
\hline
\end{tabular}

Elektronenmikroskopische Technik: In allen Fällen wurde das Material sofort nach Dekapitation entnommen und mit Paradeschen Flüßigkeit ( $\mathrm{pH} 7.6$ ) 2 Stunden fixiert, in Alkohol entwassert und in Epon 812 eingebettet. Die Dünnschnitte wurden mit einen Porter-Blum-Mikrotom hergestellt und mit gesättigter Uranylazetatlösung nachkontrastiert. Aufnahmen: Hitachi HS 11A.

\section{Befunde}

In den histologischen Lehrbüchern beteiligen sich Pinealzellen, Neuroglia, Bindegewebe sowie Gefäße am Aufbau der Zirbeldrüse. Jedoch kann man elektronenmikroskopisch keine wesentliche Unterschiede zwischen den Pinealzellen und Gliazellen finden. Den größten Teil der Pinealzellen nimmt meist der ovoide, chromatinreiche Kern ein. Das Zytoplasma ist der spärlich ausgebildete Mantel, in dem sich die Zellorganelle nur ganz gering entwickeln. Im Zytoplasma treten mitunter kugelige, mitunter bizarre elektronendichte Granula in dem von etwa 1,400 3,500 $\AA$ Durchmesser auf. Auf Grund der histochemischen Beobachtung werden sie den Pigment-oder Lipoidgranula entschieden. Man kann die elektronenmikroskopischen Bilder nie treffen, die sich der GolgiApparat, sowie das endoplasmatische Retikulum in der Pinealzellen an der Produktion dieser Granula beteiligen; die Granula sind deshalb keine durch sekretorische Tätigkeit der Pinealzellen produzierten Substanzen. Außer den Pigment- und Lipoidgranula findet man auch die Lysosom-ähnlichen Körperchen in den Perikaryen der Pinealzellen.

Die Kapillarrohre in der Epiphyse werden von deutlich abgrenzbaren, nicht porös gebauten Endothelzellen ausgekleicet. Die Basalmembran, die stellen- 
weise aus zwei äußeren dunklen und einer mittleren hellen Schichten besteht, liegt zwischen nervösen Elemente und Endothelzellschicht. In der Umgebung bilden die feinen Zellausläufer ein dichtes Fasergeflecht. In dieser Arbeit möchte der Autor die Frage über den Ursprung von den Ausläufern nicht berücksichtigen; die Frage, ob die Fortsätze entweder aus den Pinealzellen in der Zirbeldrüse oder Nervenzellen im Zwischenhirn stammen, wird durch die histochemisch-elektronenmikroskopische Untersuchung nicht vollkommend gelöst. Die Ausläufer scheint wahrscheinlich an der Basalmembran der Blutkapillaren oder selten im Perikapillärraum zu enden. Und die Endigungen zeichnen sich oft neben den Mitochondrien durch die Einlagerung zahlreicher Bläschen aus, deren Durchmesser etwa $500 \AA$ beträgt. Diese Bläschen enthalten fast alle kleine elektronendichte Granula. In der elektronenmikroskopischen Untersuchung an der Epiphyse von Ratte haben De Robertis \& De Iraldi (1961) dieselbe Granula beobachtet und folgenden Schluß gezogen: Diese Bläschen haben eine auffallende Ähnlichkeit mit den synaptischen Bläschen in den sympathischen Nervenfaserendigungen, infolgedessen entsprechen sie den Catecholamin-Partikeln. Nach beiden Autoren wird diese Überträgerstoffe im Zytoplasma der Pinealzellen produziert. Jedoch, wie oben erwähnt, hinkt der sichere Beweis, daß die Endigungen in der Umgebung der Blutkapillaren die Fortsätze der Pinealzellen sind, und auch kann man nicht nachweisen, daß die Granula unter Mitwirkung von Zellorganellen im Zytoplasma der Pinealzellen entstanden werden. Im Gegenteil der Meinung von Gusek und Santoro (1961) bleibt die Frage nocb unlöslich, ob die Epiphyse bei Säugetieren ein echtes inkretorisches Organ ist. Außerdem reagieren die Epiphyse von Hund und Katze gar nicht auf den Reaktionen für Monoaminoxydase und Catecholamin, während bei Ratte die Pinealzellen auf der MAO-Reaktion deutlich positive reagieren (Shimizu 1964, Smith 1963). Daher ist es auch noch fraglich, daß die in den Endigungen nachweisbaren Granula bestimmt die Catecholamin-Partikeln sind.

\section{Zusammenfassung}

Die Epiphyse von Hund, Katze und Ratte wurde histochemisch und elektronenmikroskopisch untersucht.

1. Die histochemischen Reaktionen für die verschiedenen Stoffe unterliegen beträchtlichen vergleichend-anatomischen Schwankungen (s. Tabelle).

2. Die strukturellen wesentlichen Unterschiede zwischen Pinealzellen und Gliazellen wurden elektronenmikroskopisch nicht beobachtet.

3. Die Perikaryen der Pinealzellen enthalten außer den bekannten Organellen der Gliazellen elektronendichte Pigmentgranula, Lipoidtröpfen sowie Lysosomen. Die sekretorische Tätigkeit in den Perikaryen der Pinealzellen wurde elektronenmikroskopisch nicht nachgewiesen.

4. Die an Kapillarwand endigten Zellausläufer bilden ein dichtes Fasergeflecht. Die kolbig verdickten Endigungen enthalten sehr viele "synaptische Bläschen"-ähnliche Bläschen. Der Durchmesser der Körnchen beträgt etwa $500 \AA$. In der Arbeit wurde auch das Wesen dieser Granula diskutiert. 


\title{
Literatur
}

Bargmann, W. (1943) Mrllendorff's Handbuch der mikroskopischen Anatomie des Menschen, IV. Teil, S. 309. De Robertis, E. \& A.P.De Iraldi (1961) J. Biophy. Biochem. Cytol., 10, 361. Gusek, W. u. A. Santoro (1961) Endokrinol., 41, $105 . \quad$ Shimizu, N. (1964) Advances in Neurological Sciences, 8, 486. (Japan.) Smith, B. (1963) J. Anat., Lond., 94, 81.

\section{Enzyme Histochemistry in Experimental Diabetes Mellitus. The findings of several enzyme activities in pancreatic islet cells.}

\author{
Nobuo IHARA \\ Department of Pathology (Prof. R. Maeda), Kansai Medical School, Moriguchi, Osaka,
}

\section{Excerpts}

The findings in various enzyme activities in the pancreatic islet cells from alloxan and dithizone diabetic rabbits (one to two months after the induction of diabetes) were investigated.

In this investigation, the present author devised the "series section method" and applied it for the differentiation of A- and B-cells on the sections stained for enzyme activities, comparing them with the other sections stained with Gomori's chromehematoxylin-phloxin method at the same time.

As for the G-6-PD, the ACPase, the ATPase, the LD.DPND and the SD activities, almost the same reaction in both $A$ - and B-cells was observed in the normal pancreatic islets. On the other hand, G-6-Pase activity was stronger in B-cells.

In the diabetic islets, the activities of G-6-PD, ACPase and ATPase showed a decrease in both A- and B-cells, particularly in the latter. The findings of G-6-Pase in B-cells were not constant, being dependent on the individual cells and islets. However, in general, in many cells and islets a distinct decrease was shown, whereas some B-cells which gave a stronger reaction than normal islet cells were found to have comparatively large nuclei. With regard to the variation in the activities of LD.DPND and SD, nothing striking was noted.

As summarized above, it could be assumed that the findings in the B-cells paralleled well with those in the A-cells. 